\title{
ARTICLE \\ International Protection of Foreign Investments in Offshore Energy Production and Marine Environmental Protection: Birds of a Feather or Frenemies Forever?
}

\author{
Nikolaos Giannopoulos ${ }^{1}$
}

Accepted: 2 August 2021 / Published online: 24 August 2021

(c) The Author(s) 2021

\begin{abstract}
Initially, international investment law and international law on the protection of the marine environment were two branches that developed separately. As these international regimes mature, they often speak to the same facts, bringing about their everincreasing normative interaction, way before any disputes arise. The regulation of investments in offshore energy production is chosen as a case study because it exemplifies how these two bodies of international law can interact. The article does not conceptualize these two international regimes as inherently antagonistic but instead highlights their potential complementarity. Yet, it is primarily the issue of normative conflicts between those two regimes which has generated heated scholarly debates. Against the backdrop of sweeping critiques about the potential 'regulatory chill' of international investment agreements and their investor-State dispute settlement mechanism, this contribution examines whether arbitral tribunals have interpreted and applied investment rules in a fashion that can unduly restrict the discretion of host States to honour their marine environmental obligations. First, it explores why and how international investment law and marine environmental law interact and influence each other's implementation. In a second step, the article investigates the impact (if any) of investment obligations on the discretion of host States to comply with their marine environmental protection obligations. Adopting a forward-looking perspective, it finally enquires into the potential impact of the reformed provisions under new generation IIAs on the right and duty of States to take all necessary measures to protect the marine environment against pollution from offshore energy production activities.
\end{abstract}

Keywords Offshore energy · International investment law $\cdot$ Marine environmental law $\cdot$ Normative interactions $\cdot$ Systemic integration $\cdot$ IIAs reform

\footnotetext{
This article is based on Chapter 4 of the author's $\mathrm{PhD}$ thesis, 'International Law and Offshore Energy Production: Marine Environmental Protection through Normative Interactions' (Utrecht University 2020, unpublished).
}

Extended author information available on the last page of the article 


\section{Introduction}

Investments are the 'lifeblood' at the heart of offshore energy production, ${ }^{1}$ as the exploitation of energy resources has heavily depended on the large flow of foreign capital and technological expertise. ${ }^{2}$ The offshore energy sector of most countries has been primarily controlled by multinational energy companies operating under long-term exploitation concessions and production-sharing agreements. ${ }^{3}$ Offshore energy investments are not only crucial to meet the increasing demands in energy consumption, but also to maintain the levels of energy production capacity because much of the current offshore energy infrastructure is approaching the decommissioning phase. ${ }^{4}$

Against the backdrop of heated debates about climate change mitigation, States have also relied on large-scale foreign investments to increase their production of energy from renewable sources. ${ }^{5}$ For instance, the EU Offshore Renewable Energy Strategy has recently stressed that private investments in marine renewables are indispensable for the EU to meet its climate commitments, safeguard energy security and improve the competitiveness of the EU energy market. ${ }^{6}$ Similarly, the International Energy Agency (IEA) has reported that a sustainable development scenario, according to which States can get on track with their climate change and energy access goals, presupposes an additional 4.6 trillion US dollars in capital offshore energy investment by $2040 .^{7}$

Like investments in onshore energy infrastructure, investments in offshore energy projects tend to be long term, capital intensive and largely dependent upon the exercise of the State's regulatory powers. ${ }^{8}$ Once platforms for the exploitation of offshore energy are installed, the investors are regulatory 'hostages' of the host State for a long period, which is often required before there is a reasonable return on the investments. ${ }^{9}$ During that period, the investors are exposed to considerable political and regulatory risk, because unforeseen changes in the legal environment of the host State may seriously undermine their financial feasibility or even result in the expropriation of the investment altogether. ${ }^{10}$ In fact, amendments in the framework governing the offshore energy sector-often induced by international commitments

\footnotetext{
1 OECD, IEA and IRENA, 'Perspectives for the Energy Transition: Investment Needs for a Low-Carbon Energy System' (2017), p. 23, http://www.irena.org/publications/2017/Mar/Perspectives-for-the-energytransition-Investment-needs-for-a-low-carbon-energy-system (accessed 30 April 2021).

2 Trevisanut et al. (2013), p. 247.

3 Mbengue and Raju (2014), p. 173.

4 Trevisanut (2020a, b), p. 431.

5 Hanni et al. (2011), pp. 28-30.

6 Communication from the Commission to the European Parliament, the Council, the European Economic and Social Committee and the Committee of the Regions, 'An EU Strategy to harness the potential of offshore renewable energy for a climate neutral future', COM/2020/741 final.

7 IEA, 'World Energy Investment: Executive Summary' (2017), https://www.iea.org/Textbase/npsum/ WEI2017SUM.pdf (accessed 30 April 2021).

8 Whitsitt and Bankes (2013), pp. 210-211; Wälde and Kolo (2001), p. 819.

9 Cotula (2008), p. 158; Martin (2011), p. 332.

10 Joffe et al. (2009), pp. 3-23; Seck (1996), pp. 114-116.
} 
to protect the marine environment and fight climate change- have triggered investment disputes against host States and, for the first time, against the EU itself. ${ }^{11}$ The decisions of Germany and the Netherlands to phase out nuclear and coal energy generation, respectively, offer a representative example of how environmental policy decisions can have a grave impact on long-term energy investments and trigger investment disputes. ${ }^{12}$ In 2019, an Austrian company launched arbitral proceedings against Germany under the Energy Charter Treaty (ECT), claiming that the amendments of the German Renewable Energy Sources Act have negatively affected its offshore wind farm investment. ${ }^{13}$ Similarly, the decision of Italy to reimpose a moratorium on the exploitation of offshore energy resources in the Ombrina Mare field due to its proximity to a natural reserve area, pending an application for an offshore oil production concession agreement in that area by a foreign company, is currently being examined as an alleged breach of its international investment obligations in an ongoing case before an International Centre for Settlement of Investment Disputes (ICSID) Tribunal. ${ }^{14}$

In this context, this article analyses the potential normative impact of interactions between international investment and marine environmental rules regulating foreign investments in offshore energy production. After this introduction, the second section explores why and how international investment law and marine environmental law interact and influence each other's implementation. The third section investigates the impact (if any) of investment obligations on the discretion of host States to comply with their marine environmental protection obligations. Relevantly, it examines whether investment disciplines, as they have been interpreted and applied by investment tribunals, can unduly restrain States' regulatory discretion as suggested by fierce critics of international investment law and its investor-State dispute settlement mechanism (ISDS). The fourth section adopts a forward-looking perspective and enquires into the potential impact of the reformed provisions under new-generation international investment agreements (IIAs) on the right and duty of States to take all the necessary measures to protect the marine environment against pollution from offshore energy production activities.

\footnotetext{
11 Nord Stream 2 AG v. European Union, PCA Case No. 2020-07 (pending).

12 Vatenfall $A B$ and Others v. Federal Republic of Germany, ICSID Case No. ARB/12/12; Romanin Jacur (2015), pp. 339-356; RWE AG and RWE Eemshaven Holding II BT v. Kingdom of the Netherlands, ICSID Case No. ARB/21/4; Uniper SE, Uniper Benelux Holding B.V. and Uniper Benelux N.V. v. Kingdom of the Netherlands, ICSID Case No. ARB/21/22.

13 Strabarg SE, Erste Nordsee-Offshore Holding GmbH and Zweite Nordsee-Offshore Holding GmbH v. Federal Republic of Germany, ICSID Case No. ARB/19/29, Partial Award on Jurisdiction of 2 March 2020 (Award on merits pending).

14 Rockhopper Exploration Plc, Rockhopper Italia SpA and Rockhopper Mediterranean Ltd v. Italian Republic, ICSID Case No. ARB/17/14, Decision on Intra-EU Jurisdictional Objection of 26 June 2019 (Award on merits pending).
} 


\section{Do Opposites Attract? Normative Interactions Between International Investment Law and Marine Environmental Law}

The ongoing and projected proliferation of offshore energy investments poses significant risks to the environmental status of seas and oceans. ${ }^{15}$ Although marine renewables have been promoted without much consideration for the potential environmental risk-shifting, ${ }^{16}$ both traditional and renewable energy production at sea have significant environmental repercussions. ${ }^{17}$ The interconnectedness of the oceans, the lack of scientific certainty on the long-term and cumulative effects of emerging technologies used in the exploitation of marine energy resources, coupled with the fundamental erga omnes obligation ${ }^{18}$ of States to protect and preserve the marine environment, create real challenges for the regulation of offshore energy investments. Against such a background, international investment law cannot operate in isolation from the broader international legal framework regulating the environmental externalities of offshore energy projects. The obligations of States under the United Nations Convention on the Law of the Sea (UNCLOS) ${ }^{19}$ and several environmental agreements on the protection of the marine environment against risks from offshore activities ${ }^{20}$ have considerable implications for the regulation of energy investments at sea. ${ }^{21}$ That being said, the article does not conceptualise IIAs and marine environmental rules as two diametrically opposite legal regimes but highlights their potential to also operate synergistically.

\subsection{The Potential Frictions Between International Investment and Marine Environmental Law}

Besides international investment law, marine environmental law also shapes the exercise of the sovereign right of host States to regulate the operation of offshore energy investments. Even though those international law 'fragments' ${ }^{\text {'2 }}$ have mainly developed independently from each other, they are creating partly overlapping obligations for States, as they both aim to influence States' exercise of authority in regulating the exploitation of their offshore energy resources. In other words, they both try to frame the content of the 'right to regulate', which is a fundamental attribute of sovereignty under international law. ${ }^{23}$

\footnotetext{
15 Trevisanut and Giannopoulos (2018), p. 791.

16 On the concept of problem shifting see Kim and van Asselt (2016), pp. 475-477.

17 Ludeke (2018), pp. 168-174.

18 Sicilianos (2002), pp. 1136-1137.

19 United Nations Convention on the Law of the Sea, 1833 UNTS 397.

20 Giannopoulos (2019), pp. 302-303.

21 Responsibilities and Obligations of States Sponsoring Persons and Entities with respect to Activities in the Area, ITLOS Reports 2011, paras. 117-120.

22 Inter alia, Pauwelyn (2004), pp. 903-905.

23 Mann (2002), p. 5.
} 
Even though both these bodies of international law are trying to carve out the exercise of the regulatory discretion of States, ${ }^{24}$ international investment law and international environmental law pursue-at least prima facie-different objectives. Most of the first generation of IIAs (until approximately 1992) were focused on the protection of foreign investments and did not contain any clauses relating to environmental protection. ${ }^{25}$ The relative autonomy of international investment and international environmental law, as specialised fields of international law, explains why interplay and cross-references between them were somewhat limited in their early stages of development. ${ }^{26}$ From a normative perspective, the interactions between international investment law and international environmental law have their origins in the parallel proliferation of IIAs ${ }^{27}$ and the progressive diversification of international rules, which seek to protect and preserve the marine environment against pollution stemming from economic activities, such as offshore energy generation.

The most noticeable confirmation of the increasing interactions between these branches of international law is the surge in investment disputes relating to environmental issues. ${ }^{28}$ There is a growing perception that the expansive interpretation of investment protection disciplines can encroach upon and conflict with the implementation of international environmental obligations. In particular, foreign investors increasingly challenge regulatory measures adopted in pursuance of environmental protection by host States, claiming that these measures breach investment protection obligations. ${ }^{29}$ These normative interactions can result in a genuine conflict when the host State cannot comply with all the requirements set by simultaneously applicable investment and environmental obligations and its choice to prioritise compliance with one of them would necessarily or potentially entail the failure to comply with the other one. ${ }^{30}$ In other words, a legal conflict arises when the content of simultaneously applicable international investment and environmental rules requires the exercise of contradictory conduct by the host State, or when one norm permits certain conduct which is explicitly prohibited by the other applicable norm. ${ }^{31}$ The problem is that, in the case of such horizontal normative conflicts, ${ }^{32}$ there is no a priori hierarchy among rules of different branches of international law. ${ }^{33}$ As a matter of principle, investment obligations do not prevail over international marine environmental obligations nor do the latter trump the former. Because none of these norms qualifies as jus cogens, ${ }^{34}$ their conflicts are governed

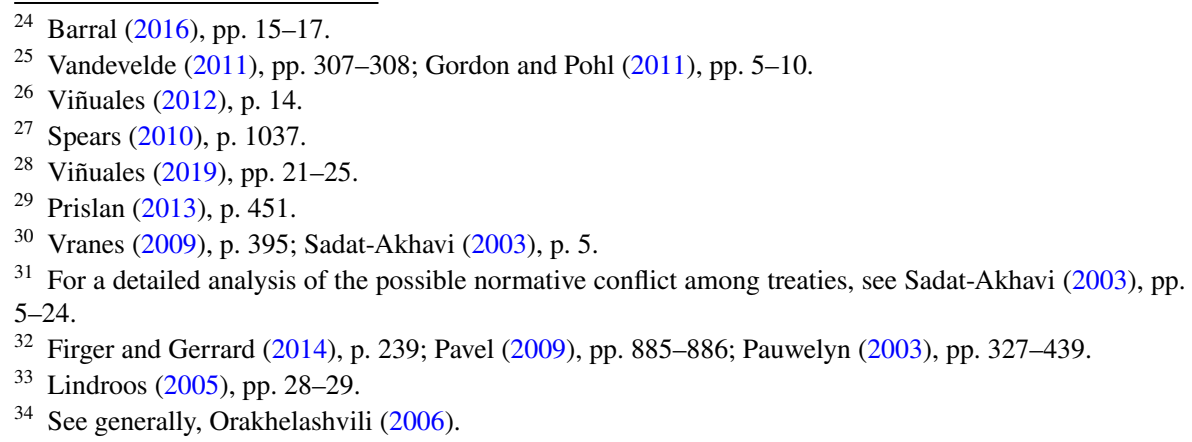


by either specific clauses under the agreements in question, or by the treaty-conflict rules under the law of treaties. ${ }^{35}$

\subsection{The Potential Complementarity Between Investment and Marine Environmental Protection}

Despite the obvious tensions, the interactions between investment protection rules and rules on the protection of the marine environment are not necessarily or inherently conflictory. ${ }^{36}$ Their interactions can also be neutral or synergistic. For instance, legal obligations relating to the protection of investments and those relating to the preservation and protection of the marine environment can co-exist without giving rise to any conflict, when obligations stemming from these two branches of international law do not even speak to the same issues. In such a case, host States will be able to fully comply with both their investment and marine environmental obligations simultaneously. ${ }^{37}$ In addition, interactions between legal rules belonging to these legal regimes can even result in their cross-fertilisation, in the sense of complementing or reinforcing each other. ${ }^{38}$ For instance, investors have relied on separate treaty regimes, such as human rights or environmental agreements, to claim that their complementary application should be interpreted as broadening the standard of investment protection accorded to them under IIAs. ${ }^{39}$

Investment tribunals generally enjoy considerable discretion regarding the applicable rules in investment disputes under most IIAs. ${ }^{40}$ However, even when the relevant applicable law clauses under IIAs limit the capacity of tribunals to apply other rules of international law, the provisions of IIAs can be interpreted in the light of environmental obligations, either when the former contain 'evolutionary' terms or through systemic interpretation according to Article 31(3)(c) of the Vienna Convention on the Law of Treaties (VCLT). ${ }^{41}$ When the IIA does not define the precise normative content of its rules, the interpreter can use the flexibility of open-ended terms, such as 'fair and equitable treatment' or 'like circumstances' and refer to other rules of international law to determine their meaning in a specific case. ${ }^{42}$ The

\footnotetext{
35 Michaels and Pauwelyn (2012), pp. 366-371.

36 Trevisanut and Giannopoulos (2018), pp. 826-827.

37 Suez Sociedad General de Aguas de Barcelona SA and Interagua Servicios Integrales de Agua SA v. Argentine Republic, ICSID Case No. ARB 03/17, Decision on Liability of 30 July 2010, para. 262.

38 Hirsch (2006), p. 5.

39 Inter alia, see Spyridon Roussalis v. Romania, ICSID Case No. ARB/06/01, Award of 7 December 2011, where the investor sought to read the standard of protection of the right to property under the European Convention on Human Rights (ECHR) into the standard of protection against expropriation under the applicable IIA.

40 According to the ICSID tribunal in Emilio Agustin Maffezini v. Kingdom of Spain, ICSID Case No. $\mathrm{ARB} / 97 / 7$, paras. 65-71, EU and international law relating to the obligation to conduct an EIA before the construction of a chemical plant were part of the applicable law in the dispute before it.

41 Urbaser S.A. and Consorciode Aguas Bilbao Bizkaia, Bilbao Biskaia Ur Partzuergoa v. the Argentine Republic, ICSID Case No. ARB/07/26, Award of 8 December 2016, paras. 1198, 1200-1203; Simma (2011), p. 573.

42 Mills (2014), pp. 453-454
} 
systemic interpretation of the competing obligations can serve as a tool to reconcile their normative requirements by 'interpreting away' any initially identified incompatibility between them. ${ }^{43}$ However, Article 31(3)(c) of the VCLT does not enable arbitral tribunals to apply other rules of international law directly, nor defer to their normative contours, because its purpose is to clarify the meaning of the interpreted rules. ${ }^{44}$ An investment tribunal, due to its mandate, will inevitably interpret the examined IIA in the light of the other applicable rules of international law. ${ }^{45}$ That being said, the precise impact of taking other rules into account can only be evaluated on a case-by-case basis: systemic interpretation can either clarify IIA rules to the benefit of investment protection or demarcate the limits of such protection to avoid friction with competing public interests. ${ }^{46}$

The particularities of ISDS further accentuate the potential interactions between international investment law and international marine environmental law. ${ }^{47}$ The enhanced enforceability of investment law through the sui generis investment arbitration proceedings increases the likelihood that investment tribunals will need to determine the impact of international environmental norms on the outcome of the dispute before them. Arguably, the recent stance of investment tribunals illustrates that they have moved from an isolationist position towards acknowledging the significance of non-investment obligations, ${ }^{48}$ but have not yet expressed a genuine will to integrate such obligations into the application of investment law. ${ }^{49}$ The crux of the matter is, however, whether investment tribunals interpret and apply IIAs in a fashion that can disproportionately constrain the regulatory discretion of host States to honour their marine environmental protection commitments. ${ }^{50}$

\section{The Impact of IIAs on the Implementation of Marine Environmental Obligations}

Having examined the potential normative interactions between international investment and marine environmental law, this section analyses how investment obligations may affect the exercise of the right and duty of States (under environmental law) to adopt measures to protect the marine environment, insofar as such measures can adversely affect foreign investments. In that respect, it argues that critiques that IIAs and ISDS result in 'regulatory chill' ${ }^{51}$ as well as arguments about the 'investor

\footnotetext{
43 McLachlan (2005), p. 286.

44 Gardiner (2017), p. 271.

45 Trevisanut et al. (2020), pp. 17-18.

46 Schill and Djanic (2018), p. 45.

47 Di Benedetto (2013), p. 15.

48 Urbaser v. Argentina, supra n. 41, para. 1192.

49 Acconci et al. (2014), p. 181; Hirsch (2008), pp. 321-343.

50 Spears (2010), p. 1039.

51 Regulatory chill refers to the conception that States might refrain from updating and upgrading environmental standards to maintain their competitive advantage against third States in attracting foreign investments or due to the fear that such environmental regulation could increase the risk of investor-State
} 
bias $^{52}$ of the investment regime are unsubstantiated according to the findings of recent empirical studies ${ }^{53}$ and have no anchoring in the practice of investment arbitration. ${ }^{54}$ These arguments are primarily rooted in the conception that States surrender their sovereign right to regulate in order to honour their freely and voluntarily undertaken duties under IIAs. ${ }^{55}$ However, the author posits that the 'regulatory chill' argument suffers from an inherent subjectivity, which makes it difficult to refute outright based on empirical data, as the fact that it "cannot be measured may help those who support the theory when influencing public opinion'. ${ }^{56}$ One should also, perhaps, keep in mind that ISDS does not seek to promote itself as a means to achieve adjudicatory ideals, such as environmental justice. ${ }^{57}$

The recent practice of arbitral tribunals reveals that investment disciplines do not require absolute regulatory stability, but instead, they call for the credibility of specific commitments to investors. ${ }^{58}$ Many IIAs explicitly preserve the host States' right and duty to pursue non-investment commitments and adapt the legal framework governing investments in pursuit of legitimate public policy objectives, such as marine environmental protection. As is further discussed below, environmental considerations have increasingly been accommodated by investment tribunals in a way that allows host States considerable leeway in complying with their international commitments, inter alia, to protect the marine environment. In particular, the following analysis focuses on two investment protection standards, which are most commonly invoked by investors in cases involving the right of States to regulate, namely the protection against expropriation and the fair and equitable treatment (FET) standard.

\subsection{The Standard of Protection Against (Indirect) Expropriation Under IIAs and the Right and Duty of Host States to Adopt Marine Environmental Measures}

In most environmentally relevant investment disputes, investors claim that the introduction, amendment or even termination of environmental measures amount to indirect or regulatory expropriation of their investment. ${ }^{59}$ This assertion is particularly significant in the offshore energy sector, where environmental standards are

\footnotetext{
Footnote 51 (continued)

arbitration and the consequent awarding of compensation to the investors. See Tienhaara (2011), p. 606; Miles (2008), pp. 22-24.

52 See the UNCITRAL Working Group III papers available at: https://uncitral.un.org/en/working groups/3/investor-state (accessed 30 April 2021).

53 Empirical research has revealed that ISDS does not have a 'chilling' effect on environmental regulation, see Laudal Berge and Berger (2019), pp. 1-41; Behn et al. (2018), pp. 333-389.

54 Baker and Dowling (2019), p. 39; Mann (2015), pp. 1-5.

55 Baltag and Dautaj (2019), p. 47.

56 European Federation of Investment Law and Arbitration, 'A response to the criticism against ISDS', https://efila.org/wp-content/uploads/2015/05/EFILA_in_response_to_the-criticism_of_ISDS_final_draft. pdf (accessed 30 April 2021).

57 Baltag and Dautaj (2019), p. 6.

58 Bellantuono (2017), p. 287.

59 Viñuales (2019), p. 20.
} 
regularly updated to respond to changes in technology and scientific evidence. ${ }^{60}$ In light of the reasoning of investment tribunals, it appears that the typical commercial risks associated with the regulation of offshore energy activities cannot be considered as amounting to indirect expropriation, as they do not reach the required high threshold of interference with the value of investments. In addition, this section describes how recent investment awards have managed to strike a balance between seemingly competing international obligations of host States through the application of the 'police powers' doctrine and the test of proportionality in the context of the standard of protection against expropriation.

\subsubsection{Internationally Induced Marine Environmental Measures and Their Degree of Interference with the Value of the Foreign Investment}

Traditionally, the possibility of unlawful expropriation of an investment's assets by the host State has been among the most significant risks faced by foreign investors in the energy sector. ${ }^{61}$ Although international law does not categorically prohibit any taking of the property of foreign investors, ${ }^{62}$ IIAs impose certain conditions on the lawful exercise of the right of States, namely to expropriate for a public purpose, in a non-discriminatory manner, following due process and accompanied by the payment of prompt, adequate and effective compensation. ${ }^{63}$ IIAs usually provide for the protection of foreign investments against expropriation referring to both 'direct' and 'indirect', 'creeping' or 'regulatory' expropriation. ${ }^{64}$ In particular, indirect expropriation denotes any regulatory measures that have effects equivalent to a de facto taking of the investment either by depriving the investor, partly or in whole, of its investment or depriving the investment, partly or in whole, of its value. ${ }^{65}$ Although direct expropriation has become rare, the risk of indirect expropriation, depending on the gravity of the effects of environmental measures, appears to be still substantial for offshore energy. ${ }^{66}$ For instance, individual or cumulative environmental measures restricting offshore energy activities near marine protected areas could result in the termination of related concession agreements.

Recent awards in investment disputes have concurred that a high threshold of interference with the investment is required for regulatory measures to amount to indirect expropriation, and so have mostly rejected the relevant claims. For instance,

\footnotetext{
$\overline{60 \text { Giannopoulos (2019), p. } 302 .}$

61 In the matter of an arbitration between the Government of the State of Kuwait and the American Independent Oil Company (Aminoil), Award of 24 March 1982, 21 ILM 976; Dispute between Texaco Overseas Petroleum Company/California Asiatic Oil Company and the Government of the Libyan Arab Republic and Others, Award of 19 January 1977, 17 ILM 1 (1978).

${ }^{62}$ UN GA Resolution 1803(XVII) of 14 December 1962, Art. 4.

${ }^{63}$ For instance, see Art. 13(1) of the Energy Charter Treaty, 2080 UNTS 100.

64 Dolzer and Schreuer (2008), p. 355.

65 Madimoil Jetoil Greek Petroleum Products Société Anonym SA v. Republic of Albania, ICSID Case No. ARB/11/24, Award of 30 March 2015, para. 569; Coop and Seif (2018), p. 225.

66 Baetens (2010).
} 
the reasoning of investment tribunals in the recent wave of disputes initiated by investors in the renewable energy sector against the reforms in their legal framework by several EU States ${ }^{67}$ confirms that regulatory measures are rarely so intrusive as to qualify as indirect expropriation. Following a series of EU directives promoting renewable energy, several EU Member States enacted legislation offering economic incentives to attract investments in renewable energy production. ${ }^{68}$ However, after investments were made, several Member States withdrew or reduced those incentives, prompting a vast number of investment claims under the ECT. ${ }^{69}$ In the context of these cases, tribunals have accepted that the withdrawal or reduction of investment promotion incentives, even when applied retroactively, are not considered as amounting to a grave devaluation of the investors' property. ${ }^{70}$ For example, in the Novenergia II v. Spain award, the investor argued that the complete elimination of the special incentives regime and the imposition of tax on renewable energy producers amounted to expropriation under Article 13(1) of the ECT. ${ }^{71}$ The tribunal considered that, even if the value of the investment had diminished as a result of the challenged measures, the property of the investor was neither expropriated nor affected by measures having effects equivalent to expropriation. In the tribunal's view, what matters was that the claimant was still the owner of the installations and the direct and indirect holder of the companies' shares. ${ }^{72}$ Thus, the investors had not suffered severe or 'radical' loss. ${ }^{73}$

As these cases indicate, regulatory measures that cause a mere reduction in the profitability of the investment do not qualify as indirect expropriation. Nevertheless, investment tribunals have not established a precise test regarding the degree of interference to determine the permissible balance between the investor's interest in regulatory stability and the need of the State to address new environmental risks or comply with new environmental standards. Tribunals retain some discretion to determine, on a case-by-case basis, whether the challenged environmental measures have rendered the value of the investment so marginal or unprofitable as to effectively deprive investments of their character. ${ }^{74}$

\footnotetext{
67 Energy Charter Treaty Secretariat, 'List of all Investment Dispute Settlement Cases', www.energychar ter.org/?id=345 (accessed 30 April 2021); Dias Simoes (2017), p. 251.

68 Selivanova (2018), p. 434; Gallagher (2018), pp. 252-256.

69 De Luca (2014).

70 Fernandez Masia (2017), p. 673.

71 Novenergia II-Energy \& Environment (SCA) (Grand Duchy of Luxembourg), SICAR v. The Kingdom of Spain, SCC Case No. 063/2015, Award of 15 February 2018.

72 Ibid., para. 758. Similarly, other tribunals considered that, despite the changes in the legal framework 'investors continued to be shareholders in the company, which continued to operate and earn revenue', see Charanne BV and Construction Investments S.A.R.L v. Kingdom of Spain, SCC Case No. 062/2012, Award of 21 January 2016, para. 462.

73 See also Isolux Infrastructure Netherlands BV v. Kingdom of Spain, SCC Case No. 153/2013, Award of 12 July 2016, para. 852 .

74 Paine (2018), pp. 203-204.
} 


\subsubsection{The Police Powers Principle as Justification for Internationally Induced Environmental Measures}

As already mentioned, a necessary condition for an expropriation to be considered as lawful is that a public purpose motivates the taking, or the equivalent to the taking, of regulatory measures. In that regard, international marine environmental obligations can legitimise the adoption of domestic implementation measures and serve as proof regarding the genuine intent underlying these measures. ${ }^{75}$ In the Chemtura v. Canada award, the tribunal found that the challenged measures were motivated by a genuine environmental objective. In particular, it concluded that the contested measures were induced by Canada's obligations under the Aarhus Protocol on Persistent Organic Pollutants to the Convention on Long-Range Transboundary Air Pollution. ${ }^{76}$ Similarly, in the Philip Morris v. Uruguay award, the tribunal's reasoning relied heavily on the obligations of Uruguay under the Framework Convention on Tobacco Control and the relevant scientific findings by the World Health Organization as proof regarding the legitimate public purpose of the challenged plain packaging scheme for tobacco products imposed by Uruguay. ${ }^{77}$ The stance of arbitral tribunals shows that, by analogy, marine environmental obligations can be relevant at least in classifying the expropriation of an investment as lawful, in the sense that it is conducted for legitimate public reasons and is not a disguise for any protectionist intent or other political purposes. ${ }^{78}$

In addition, since 2000, there has been a consistent trend in favour of differentiating between regulatory measures (often relating to environmental protection) in the exercise of the host State's police powers and indirect expropriation both in arbitral awards ${ }^{79}$ and specific provisions under IIAs. ${ }^{80}$ According to the police powers principle (or doctrine), the good faith exercise of police powers by the host State in matters such as the maintenance of public order, health or morality, excludes

\footnotetext{
75 Viñuales (2012), p. 12.

76 Chemtura Corporation (formerly Crompton Corporation) v. Government of Canada, Award of 2 August 2010, paras. 139-141.

77 Philip Morris Brands SARl, Philip Morris Products SA and Abal Hermanos SA v. Oriental Republic of Uruguay, ICSID Case No. ARB/10/7, Award of 8 July 2016, paras. 395-396.

78 Tecnicas Medioambientales Tecmed SA v. United Mexican States, ICSID Case No. ARB/00/2, Award of 29 May 2003, para. 128.

79 In the Saluka v. Czech Republic award, the tribunal noted that: 'It is now established in international law that States are not liable to pay compensation to a foreign investor, when, in the normal exercise of their regulatory powers, they adopt in a non-discriminatory manner bona fide regulation that are aimed to the general welfare'. According to its view 'the principle that the State adopts general regulations that are commonly accepted as within the police powers of States forms part of customary international law today', Saluka Investments BV v. Czech Republic, PCA Partial Award of 17 March 2016, paras. 255, 260, 262.

80 See, for instance, the 2004 and 2012 US Model BIT provisions on expropriation: 'Except in rare circumstances, non-discriminatory regulatory actions by a Party that are designed and applied to protect legitimate public welfare objectives, such as public health, safety, and the environment, do not constitute indirect expropriation'. Similar provisions are included in several IIAs, like the Canada Model BIT, and the EU-Canada Comprehensive Economic and Trade Agreement, see CETA Annex 8-A, Expropriation, Art. 3, and the EU-Singapore Free Trade Agreement, Annex 9-A, Expropriation.
} 
compensation even when it causes economic damage to an investor. ${ }^{81}$ Therefore, when it comes to indirect expropriation, in the light of the police powers doctrine, marine environmental obligations can be a significant factor to be considered in distinguishing between measures that constitute compensable indirect expropriation and non-compensable legitimate environmental regulations, even though they affect the economic value of investments. ${ }^{82}$ What separates indirect expropriation from regulation under the police powers of the State appears to be 'the degree of interference with the property right, the character of governmental measures, i.e. the purpose and the context of the governmental measure, and the interference with reasonable and investment-backed expectationss. ${ }^{83}$ Environmental regulations, which are generally applicable, in a non-discriminatory manner for a public purpose and following due process, are usually not considered as indirect expropriations by investment tribunals given the police powers doctrine ${ }^{84}$ unless the State had made specific commitments that it would refrain from such regulations. ${ }^{85}$ Thus, domestic measures adopted in implementation of international obligations for the protection of the marine environment against risks from offshore energy activities would, in most cases, be considered as legitimate regulation within the police powers of the State and would not qualify as indirect expropriation. ${ }^{86}$

\subsubsection{The Proportionality of the Contested as Expropriatory Environmental Measures}

Investment tribunals have also engaged in proportionality analysis to balance competing interests in examining claims of indirect expropriation. ${ }^{87}$ For instance, in the

\footnotetext{
81 'The principle that the State's exercise of its sovereign powers within the framework of its police power may cause economic damage to those subject to its powers as administrator without entitling them any compensation is undisputable', Tecmed v. Mexico, supra n. 78, para. 119. See also, Philip Morris v. Uruguay, supra n. 77, para. 295.

82 Beharry and Juritzky (2015), p. 398.

83 OECD, 'Indirect Expropriation and the Right to Regulate in International Investment Law', Working Paper No. 2004/4, https://www.oecd.org/daf/inv/investment-policy/WP-2004_4.pdf, p. 10 (accessed 30 April 2021).

${ }^{84}$ See also the Methanex case, where California's ban on the sale and use of the gasoline additive methyl tertiary-butyl ether was justified on the environmental concerns regarding its risk to groundwater and drinking water. The tribunal held that 'the California ban was made for a public purpose, was non-discriminatory and was accomplished with due process. Hence, Methanex's central claim under Article 1101(1) of expropriation under one of the three forms of action in that provision fails. From the standpoint of international law, the California ban was a lawful regulation and not an expropriation', Methanex v. United States, Case No. ARB/98/3, Award of 3 August 2005, Part IV, ch. IV, para. 15.

85 'A non-discriminatory regulation for a public purpose, which is enacted in accordance with due process and, which affects, inter alios, a foreign investor or investment is not deemed expropriatory and compensable', Methanex v. United States, supra n. 84, Part IV, ch. D, para. 7. Similarly, it has been upheld that 'the principle that a State does not commit an expropriation and is thus not liable to pay compensation to a dispossessed alien investor when it adopts general regulations that are commonly accepted within the police powers of States forms part of customary law today', Saluka Investments BV $v$. the Czech Republic, supra n. 79, para. 262.

86 Nowrot (2014), p. 628.

87 Ortino (2017), p. 73; Henckels (2012), p. 235.
} 
Tecmed v. Mexico award, the tribunal noted that 'there must be a reasonable relationship of proportionality between the charge or weight imposed to the foreign investor and the aim sought to be realized by any expropriatory measure' ${ }^{88}$ In the tribunal's opinion, a compensable indirect expropriation only occurs when measures result in disproportional restrictions on the interests of the investor. In evaluating the measure's proportionality, the tribunal considered several factors, including the importance of the objective pursued by the host State, the weight and the effects on the investor's property as well as the legitimate expectations of the investor. ${ }^{89}$ In upholding that the host State could have adopted measures that would have had a less excessive effect on the investor's property, ${ }^{90}$ the tribunal concluded that the challenged measures affected the investment disproportionately and, thus, amounted to indirect expropriation.

As reflected in the reasoning of many international and domestic courts and tribunals, proportionality analysis entails three cumulative sub-elements. First, it requires the challenged measures to be effective in contributing to the purported objective (suitability); second, they must be necessary to achieve the objective (necessity); and third, the measures must not bear an excessive impact on the claimant's interest compared with the benefits to the community or public interest (proportionality stricto sensu). ${ }^{91}$ Among them, the third element of the proportionality analysis, namely the stricto sensu proportionality of the examined measures, can be malleable to judicial preferences. ${ }^{92}$ That is because the third stage of review requires the tribunal to weigh the two competing interests to evaluate whether, in its opinion, the measure's impact is too severe in comparison with the gain that it purports to achieve. Relevantly, it has been suggested that investment tribunals should adopt a deferential implementation of the third stage of the proportionality analysis to respect the discretion of the host State in choosing the exact measures that the State regards as stricto sensu necessary to deal with a complex environmental problem. ${ }^{93}$ In other words, tribunals should not substitute themselves in the role of the host State but rather examine whether the effects of the measures in question are obviously disproportionate compared with the pursued environmental protection objective. ${ }^{94}$

\footnotetext{
${ }_{88}$ Tecmed v. Mexico, supra n. 78, para. 112.

89 Ibid., para. 149.

90 Similarly, in the SD Myers v. Canada award, the tribunal balanced the purpose and effects of the measure and examined whether the State could have adopted alternative measures with a milder effect on the investment to determine whether the challenged measure would be justified as within Canada's police powers, SD Myers Inc v. Government of Canada, UNCITRAL Partial Award of 13 November 2000, paras. 215, 221.

91 Henckels (2012), pp. 225-227.

92 Kingsbury and Schill (2010), p. 78.

93 Ortino (2017), pp. 87-90.

94 Acconci et al. (2014), pp. 182-183.
} 
Despite the slightly inconsistent manner in which arbitral tribunals analyse proportionality, their increasing tendency to examine the reasonableness ${ }^{95}$ of the challenged measures in the context of indirect expropriation could indicate that at least some elements of the proportionality analysis are crystallising as a requirement for the police powers doctrine to defeat a claim of compensable expropriation. ${ }^{96}$ Proportionality analysis has the potential to operate as a useful tool in accommodating the host State's interest in complying with its environmental obligations, as it facilitates the balancing of the interest of investment protection with competing community interests such as the protection of the marine environment. ${ }^{97}$

\subsection{The FET Standard and the Right and Duty of Host States to Adopt Marine Environmental Measures}

The FET standard requires host States to encourage and create stable, equitable, favourable and transparent conditions for investors. ${ }^{98}$ Given the fact that it does not provide for a hard and fast rule, it has often operated as the 'default' standard of protection in investment disputes. ${ }^{99}$ Notably, when the challenged measures do not affect the property of the investor to such a degree as to amount to indirect expropriation, claimants rely on the FET standard. ${ }^{100}$ The tension usually arises out of the fact that foreign investors in long-term and capital-intensive projects operating in a heavily regulated environment, such as offshore energy production, need to calculate their investment's regulatory risks in advance because changes in the legal framework imposed by the host State have the potential to frustrate their expectations regarding economic revenues. ${ }^{101}$ From the host State's perspective, it is essential to maintain some discretion in responding to changes in environmental standards, to the increasing level of risk posed by technological developments, as well as to the developing scientific awareness about those risks and the measures that are appropriate in mitigating them. In the words of the tribunal in the Madimoil v. Albania award,

economic, social, environmental, and legal circumstances and problems are by their very nature dynamic and bound to constant change. It is indispensable for successful public infrastructure and public services to exist that they are adaptable to these changes. Accordingly, State policy must be able to evolve in

\footnotetext{
95 Instead of engaging explicitly in proportionality analysis, tribunals have often referred to the test of reasonableness to examine whether there is an 'appropriate correlation between the State's public policy objective and the measure adopted to achieve it'. Reasonableness is associated with both the nature of the measures and the way they are implemented. See AES v. Hungary, ICSID Case No. ARB/07/22, Award of 22 September 2010, paras. 10.3.7-10.3.9.

96 Henckels (2012), p. 254.

97 Bertoli et al. (2014), p. 42.

98 See Art. 10(1) of the ECT.

99 Schreuer et al. (2007), p. 92.

100 Dolzer and Scheuer (2008), p. 130.

101 Hirsch (2011), p. 783.
} 
order to guarantee adequate infrastructure and services in time and thereby the fair and equitable treatment of investments. ${ }^{102}$

This subsection analyses the potential effects of the requirements to provide legal stability and respect the legitimate expectations of investors, as two of the most frequently invoked elements of the FET standard in investment disputes concerning environmental measures. It then moves on to evaluate how proportionality analysis under the FET standard can offer valuable balancing tools between the relevant environmental and investment obligations of the host State.

\subsubsection{The Notorious Requirement for Legal Stability under the FET Standard and Its Implications for the Implementation of Marine Environmental Obligations}

In the absence of elaborate definitions of the FET standard in many IIAs, early interpretations of its content by arbitral tribunals had considered it inseparable from the requirement of legal stability in the host State's legal environment. ${ }^{103}$ Arbitral tribunals had even supported the idea that investors could form a legitimate expectation that the general legal environment applicable at the time their investment was made would remain intact, even without any specific commitments by the host State to that end. ${ }^{104}$

Nonetheless, arbitral tribunals have recently concluded that the FET standard does not prevent host States from amending the legal framework regulating foreign investments. In particular, they have opined that the obligation of the host State to create stable conditions for investors does not equate with a stabilisation clause, but allows States to adjust their regulation in the light of changing conditions. ${ }^{105}$ Tribunals have accepted that 'a legal framework is by definition subject to change as it adapts to new circumstances day by day and a state has the sovereign right to exercise its powers which include legislative acts'. ${ }^{106}$ The requirement of fairness does not imply that the legal framework must remain untouched, but regulatory amendments must be 'made fairly, consistently and predictably, taking into account the circumstances of the investment'. 107

In the Blusun v. Italy award, the tribunal stated that when a host State needs to modify regulatory measures, it should do so in a manner which is not 'disproportionate to the aim of the legislative amendment' and with due regard to the 'reasonable reliance interests of recipients who may have committed substantial resources on the basis of the earlier regime'. ${ }^{108}$ In response to the investor's claim that the

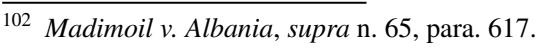

103 CMS Gas Transmission Co v. Argentina, ICSID Case No. ARB/01/8, Award of 12 May 2005, paras. 276-277.

104 Kläger (2011), pp. 247-248.

105 Coop and Seif (2018), p. 232.

106 AES v. Hungary, supra n. 95, para. 9.3.29.

107 Electrabel SA v. Republic of Hungary, ICSID Case No. ARB/07/19, Award of 25 November 2015, para. 7.77.

108 Blusun SA, Jean-Pierre Lecorcier and Michael Stein v. Italy, ICSID Case No. ARB/14/3, Award of 27 December 2016, para. 319(5).
} 
challenged measures must be evaluated in an aggregate manner, the tribunal admitted that the FET standard 'could be breached by a single transformative act aimed at an investment, or by a program of more minor measures, or by a series of measures taken without plan or coordination but having the prohibited effect'. ${ }^{109}$ However, it concluded that the FET standard, including the obligation to provide legal stability to foreign investors, has a relatively high threshold, and is only triggered in the case of 'subversion of the legal regime'. ${ }^{110}$ Similarly, the majority of the recent awards have recognised that the FET standard does not require a regulatory standstill, as such an absolute requirement would violate the sovereignty of the host State. ${ }^{111}$

Nonetheless, the FET standard requires States to exercise their sovereign rights in a certain way to accord a level of protection to investors. The crux of the matter is what kind of stability do States have to create for offshore energy investments. Interestingly, the tribunal in the Philip Morris v. Uruguay award opined that the FET standard does not prevent changes to the legal environment of investments as long as these changes do not 'exceed the exercise of the host State's normal regulatory power in the pursuance of a public interest' and do not 'modify the regulatory framework relied upon by the investor at the time of its investment outside of the acceptable margin of change'. ${ }^{112}$ However, the tribunal did not clarify what exactly is the acceptable margin of change beyond which regulatory amendments would amount to a breach of the FET standard; nor did it explain which measures would exceed the exercise of the host State's normal regulatory powers. ${ }^{113}$

The series of renewable energy investment disputes in the EU have, inter alia, examined what is the 'acceptable margin of change' within the host State's regulatory system to determine whether the challenged regulatory reforms constituted breaches of the FET standard. In the Eiser v. Spain award, the tribunal confirmed that, in the absence of specific commitments by the host State, the FET standard could not support a reasonable expectation that the legal framework governing renewable energy production would remain untouched. ${ }^{114}$ However, it entitled the investors to expect that the host State would not drastically and abruptly revise the regime, on which their investment depended, in a way that destroyed its value. ${ }^{115}$ In the view of the tribunal, the regulatory changes adopted between 2012 and 2014 by Spain crossed the red line of the margin of acceptable regulatory change because they cumulatively resulted in fundamental and unreasonable changes in the legal environment of the investments. ${ }^{116}$ Likewise, investment tribunals have applied a

\footnotetext{
109 Ibid., para. 362.

110 Ibid., para. 363.

111 For instance, see Eiser Infrastructure Limited and Energía Solar Luxembourg S.à r.l. v. Kingdom of Spain, ICSID Case No. ARB/13/36, Award of 4 May 2017, para. 362.

112 Philip Morris v. Uruguay, supra n. 77, para. 423.

113 Zannoni (2020), p. 460; Ortino (2018), p. 859.

114 Eiser v. Spain, supra n. 111, paras. 362-363.

115 Ibid., para. 387.

116 Ibid., para. 365
} 
comparable reasoning in the Masdar v. Spain and Novenergia II v. Spain awards. ${ }^{117}$ Both of the awards found for the investor, concluding that the retroactive measures adopted by Spain in 2012-2014 constituted fundamental and unreasonable changes to the regime of renewables. ${ }^{118}$

Even though it is not possible to predict the outcome of pending cases on similar matters, ${ }^{119}$ the awards issued so far concerning the regulatory changes adopted by EU Member States in relation to investments in photovoltaic plants display some consistency with regard to the acceptable margin of change under the FET standard. While the regulatory framework needs to be adaptable and reflective of changes, it should not be radically changed to deprive the investors of the total value of their investments. Even then, the FET standard cannot prevent States from exceeding the margin of regulatory change but subjects the exercise of the inalienable sovereign right of host States to regulate to the obligation to compensate the investors for any ensuing damage. ${ }^{120}$

\subsubsection{Legitimate Expectations of the Investors under the FET Standard and the Host State's Regulatory Discretion}

Forming an essential element of the FET standard, the legitimate expectations of an investor are frustrated 'when a State repudiates former assurances or refuses to give assurances that it will comply with its obligations depriving the investor in whole or significant part, of the use or reasonably-to-be expected economic benefit of its investment'. ${ }^{121}$ However, an investor cannot claim that it has formed legitimate expectations based only on the generally applicable legal framework at the time of making its investment. ${ }^{122}$ The expectation that the legal regime is not going to be radically changed cannot shield the investor from ordinary business risks. Instead, expectations must have been reasonable and legitimate in the context in which the investment was made. $^{123}$

Legitimate expectations must be based on specific assurances or representations made by the host State, without them necessarily being included in a contractual arrangement. ${ }^{124}$ According to the prevailing approach among tribunals, these assurances and promises need to be explicitly offered to the foreign investor. ${ }^{125}$ For instance, in the Charanne v. Spain award, the tribunal rejected the claim that general

\footnotetext{
117 Masdar Solar \& Wind Cooperatief UA v. The Kingdom of Spain, ICSID Case No. ARB/14/1, Award of 16 May 2018; Novenergia II v. Spain, supra $\mathrm{n} .71$.

118 Masdar v. Spain, supra n. 117, paras. 521-522; Novenergia II v. Spain, supra n. 71, para. 191.

119 Behn (2016).

120 Antaris Solar GmbH v. Czech Republic, Award of 2 May 2018, para. 360; see also Dissenting Opinion of G. Born in Antaris, para. 55.

121 Azurix Corp v. Argentine Republic, ICSID Case No. ARB/01/12, Award of 14 July 2006, para. 287.

122 Selivanova (2018), p. 441.

123 Saluka v. Czech Republic, supra n. 79, para. 304.

124 Total SA v. Argentine Republic, ICSID No ARB/04/1, Award on Liability of 27 December 2010, para. 121.

125 See also JSW Solar and Wirtgen v. Czech Republic, Award of 11 October 2017, paras. 445-446.
} 
statements made in investment promotion documents by Spain created legitimate expectations for the investors that the legal framework regulating renewables would not be modified. ${ }^{126}$ Therefore, establishing legitimate expectations becomes more complicated when the claimants seek to rely on assurances of a generic nature, such as the regulatory framework laid down when they made their investment. ${ }^{127}$ In that regard, many tribunals have recently rejected the potential of the legal framework, even if that relates to a specific group of investors, to give rise to legitimate expectations. ${ }^{128}$

When it comes to investments in offshore energy production, the host State must comply with its international obligations, for instance concerning marine safety and preparedness against accidents, for these investments to operate smoothly. Investments in offshore energy infrastructure can be severely affected if the host State does not show due diligence in protecting the marine environment within which they operate. Considering the severe repercussions of the Deepwater Horizon accident for the industry and all other economic activities in proximity, serious marine environmental harm can be assumed to hinder investments located in the marine area of a major accident. ${ }^{129}$ While such marine environmental obligations create a reasonable expectation that the domestic environmental legal framework can become gradually more stringent, ${ }^{130}$ it is arguable that such obligations do not equate the issuance of specific commitments to the investors about the adoption of specific implementation measures.

The question of whether an investor can derive legitimate expectations from environmental law obligations was dealt with by the tribunal in the Allard v. Barbados case. ${ }^{131}$ The claimant, a Canadian investor who owned a nature sanctuary in Barbados, complained that the alleged failure by the host State to take specific measures in implementing its obligations under the Ramsar Convention on Wetlands and the Convention on Biological Diversity, resulted in the pollution of his eco-tourism sanctuary, depriving him of the value of the investment. Specifically, the investor claimed that Barbados had failed to accord to his investment Full Protection and Security (FPS) under the 1996 Barbados-Canada BIT because it failed to prevent a State agency from repeatedly discharging polluted substances into the wetlands in violation of both Barbados' domestic environmental law and obligations under environmental agreements. Furthermore, the investor claimed that Barbados had failed to provide him FET because he had legitimate expectations that the host State would enforce its environmentally friendly regulatory framework. The tribunal admitted

\footnotetext{
126 Charanne v. Spain, supra n. 72, paras. 496-497.

127 Total SA v. Argentine Republic, supra n. 124, paras. 121-122.

128 Charanne v. Spain, supra n. 72, para. 493. Contra, ESPF Beteiligungs GmbH, ESPF Nr 2 Austria Beteiligungs $\mathrm{GmbH}$, and InfraClass Energie $5 \mathrm{GmbH} \& \mathrm{Co} . \mathrm{KG}$ v. Italian Republic, ICSID Case No. $\mathrm{ARB} / 16 / 5$, Award of 14 September 2020, para. 512, where the tribunal found that general legislation can contain specific representations and create legitimate expectations. See also, Greentech Energy Systems A/S, et al. v. Italian Republic, SCC Case No. V 2015/95, Award of 23 December 2018, para. 453.

129 Scovazzi (2012), p. 287.

130 Clayton and Bilcon of Dalaware Inc v. Canada, PCA Case No. 2009-04, Award on Jurisdiction and Liability of 17 March 2015, para. 738.

131 Peter A Allard v. the Government of Barbados, PCA Case No. 2012-06, Award of 27 June 2016.
} 
in an obiter dictum that, although the environmental obligations of the host State can be relevant in the application of FET and FPS standards, ${ }^{132}$ they are probably too general to create legitimate expectations regarding specific conduct by the host State. ${ }^{133}$ Nonetheless, as a matter of principle, the reasoning of the Allard v. Barbados award could be relevant for offshore energy production investments as it appears to leave room for arguing that a host State can be held liable under an IIA for not providing adequate investment protection by failing to duly comply with its environmental obligations. ${ }^{134}$ That being said, the protection of legitimate expectations under the FET standard does not require compensation for every regulatory change. It needs to be clarified that the legitimate expectations of the investor are an element to be taken duly into consideration by the host State when planning changes to the regulatory framework. ${ }^{135}$

The investor's diligence is another significant element in evaluating the reasonableness of challenged regulatory measures under the FET standard. ${ }^{136}$ The investor is expected to showcase diligence by becoming aware of the legal framework governing its projected activities, as well as the foreseeable amendments to such a framework during the life cycle of the investment. ${ }^{137}$ That is particularly important for investments in offshore energy, since the investors are usually sophisticated actors in the energy sector which cannot reasonably expect that no regulatory changes will interfere with their investments during their long-term operation. That point was highlighted in the Charanne v. Spain case, where the tribunal explicitly declared that investors in the renewable energy sector are reasonably expected to show a high standard of diligence. ${ }^{138}$ Mutatis mutandis, the legitimate expectations of foreign investors in offshore energy production projects should be evaluated considering the level of diligence they are reasonably expected to display, at least with regard to being aware of the legal framework and the likelihood of amendments, which can affect their investments. The reasonableness of their expectations needs to be examined in the light of the particularities of the sector and its environmental and societal impact, including 'business risk or industry's regular patterns'. ${ }^{139}$

\footnotetext{
132 Ibid., para. 244.

133 Ibid., para. 208.

134 Paine (2017), p. 746.

135 Saluka v. Czech Republic, supra n. 79, paras. 306-307.

136 Levashova (2020a), pp. 238-241; Viñuales (2017), p. 362.

137 Plama Consortium Limited v. Bulgaria, ICSID Case No. ARB/03/24, Award of 27 August 2008, paras. 219-221.

138 In the words of the tribunal, 'at least that is the level of care that would be expected of a foreign investor in a highly regulated sector as the energy sector, where a preliminary and comprehensive legal framework applicable to the sector analysis is essential to proceed with the investment', Charanne $v$. Spain, supra n. 72, para. 507; see also Antaris v. the Czech Republic, supra n. 120, para. 434.

139 Viñuales (2017), p. 362.
} 


\subsubsection{Proportionality Analysis and Standard of Deference Under the FET Standard}

In any event, regulatory measures need to be proportional to their purported objective. In the context of the FET standard, a proportionality analysis should consider the State's duty not to frustrate an investor's legitimate expectations, as well as the State's sovereign right and duty to take all necessary measures for the protection of public interests, such as the environment. ${ }^{140}$ States must be allowed to exercise discretion in implementing their environmental obligations, but they should not abuse this flexibility to the detriment of foreign investors. ${ }^{141}$ Therefore, the proportionality test under the FET standard enables tribunals to balance, on the one hand, the duty of the State to regulate in honouring its non-investment commitments and, on the other hand, the duty under IIAs to respect the reasonable interests of the foreign investors. The question is which standard of review has to be applied in examining the proportionality of the challenged measures.

In line with the reasoning of the tribunal in the Philip Morris v. Uruguay case, tribunals should refer and give appropriate weight to the host State's obligations under environmental law. Therefore, tribunals should adopt a deferential standard of review to allow States a margin of appreciation to ensure that they do not unduly restrain the States' ability to respect those obligations. In that respect, a higher sensitivity towards the choices of the host States when analysing the proportionality of challenged measures seems appropriate. ${ }^{142}$ Relevantly, the tribunal in the Philip Morris v. Uruguay case placed weight primarily on the lack of apparent disproportionality, focusing on the host State's efforts to comply effectively with its international obligations under the WHO Framework Convention on Tobacco Control (FCTC). In other words, the tribunal acknowledged the State's sovereign right but also the duty under its international commitments to adopt the measures to protect public health, and for that reason restricted its review to whether there was a manifest lack of reasons for the challenged measures and whether they were adopted in bad faith. ${ }^{143}$ It further accepted that it should defer to scientific findings which are made following due process and on a non-discriminatory and non-arbitrary basis. ${ }^{144}$ In the tribunal's opinion, there should be a margin of appreciation, especially when it comes to the evaluation of scientific evidence that supports the proportionality of the challenged measures. It held that there was no need to prove the actual effectiveness or utility of the measures so long as the measures were deemed to be reasonable when adopted by the host State. ${ }^{145}$

A similar standard of deference in assessing the proportionality of measures based on scientific evidence was supported by the tribunal in the Chemtura v. Canada case, according to which 'it is not within the scope of its task to second-guess the correctness of the science-based decision-making of highly specialized national

\footnotetext{
${ }_{140}$ Total v. Argentine Republic, supra n. 124, para. 123.

141 Selivanova (2018), p. 446.

142 Foster (2017), p. 288; Kingsbury and Schill (2010), p. 103; Benvenisti (2013), p. 317.

143 Yang (2018), p. 100.

144 Philip Morris v. Uruguay, supra n. 77, para. 410

145 Ibid., paras. 408-409.
} 
regulatory agencies'. ${ }^{146}$ Therefore, it can be argued that environmental measures in compliance with international obligations of the State, which are adopted following the scientific findings of treaty bodies and competent international organisations, should be presumed to be suitable to achieve their purported objective. For instance, reliance on guidelines on the implementation of EIAs by the Conference of the Parties to the Convention of Biological Diversity could serve as evidence that the host State adopted appropriate measures to mitigate environmental risks arising from the operation of marine renewable energy infrastructure. The lack of absolute scientific certainty cannot render such measures arbitrary. On the contrary, the host State can take novel measures for the protection of the marine environment, provided that they are reasonably efficient in achieving their goal. ${ }^{147}$ The test of reasonableness requires the host State to prove that there is a correlation between the objective and the measures adopted in its pursuit. Nonetheless, the stage of stricto sensu proportionality enables arbitral tribunals to find in favour of investors in a case where the measures are appropriate but have obviously excessive effects on the investments, as shown by recent awards concerning the regulatory reform of the renewables regime in Europe. ${ }^{148}$ Proportionality requires a fair balance between the need for regulatory changes and the expected environmental protection benefits with the burden posed on foreign investors. In that respect, complying with the FET standard could require a transition period to accommodate investors' interests.

Overall, the FET standard does not hinder or chill regulation aiming at addressing the environmental externalities of offshore energy investments. Instead, it is posited that investment protection standards do not unduly restrict the host State's sovereign right and duty to regulate and offer sufficient flexibility as long as the adopted measures are not discriminatory or disproportionate with regard to their environmental objectives and are subject to due process. Proper long-term planning combined with transparent and inclusive decision-making processes can ensure that any regulatory changes are in line with the host State's commitments under IIAs. ${ }^{149}$

\section{Recalibrating IIAs: The Way Forward Towards Fully Integrating Non-Investment Obligations?}

The article also posits that the wording of IIAs plays an essential role in their interpretation and, consequently, in their interaction with environmental obligations of the host State. The challenges posed by the interaction between investment law disciplines and marine environmental law obligations can differ depending on the

\footnotetext{
146 Chemtura v. Canada, supra n. 76, para. 134.

147 See Philip Morris v. Uruguay, supra n. 77.

148 Masdar v. Spain, supra n. 117, para. 512; Novenergia II v. Spain, supra n. 71, para. 681.

149 Decision of the Energy Charter Conference on Best Practices in Regulatory Reform, 11 October 2017.
} 
generation to which the IIA in question belongs. ${ }^{150}$ While the first generation IIAs gave scarce consideration to global challenges such as climate change, biodiversity conservation or the protection of public health, successive generations of IIAs have incorporated more detailed provisions regulating their relationship with other international obligations of host States. ${ }^{151}$ Parallel to the modernization of substantive standards of IIAs, the ongoing negotiations on the reform of the ISDS system under the auspices of the United Nations Commission on International Trade Law (UNCITRAL) and ICSID can also play a significant role in the recalibration of the investment regime. ${ }^{152}$ In that context, this section examines whether new developments in investment law treaty-making can reinforce the synergistic interactions between investment and marine environmental obligations, ${ }^{153}$ and allow host States to have broader discretion in complying with their duty to adopt all necessary measures to protect and preserve the marine environment.

\subsection{Refining the Content of Investment Protection Standards and the Integration of (Marine) Environmental Commitments}

Against the backdrop of the legitimacy backlash concerning investment law and ISDS, IIAs are undergoing a recalibration, as reaffirming the regulatory discretion of host States in adopting necessary measures in compliance, inter alia, with their environmental obligations and better aligning them with their climate change commitments is high on the political agenda of States. The refining of the preambles, substantive provisions, and exception clauses in IIAs is expected to limit the interpretative discretion of arbitral tribunals, which was partly due to the evaluative language of earlier IIAs. Arguably, greater precision in the formulation of the IIAs can exert greater control on behalf of States over the interpretation of IIAs ${ }^{154}$ and encourage investment tribunals to engage in a balancing exercise paying due consideration to the right (and duty) of the host State to take environmental measures. ${ }^{155}$ That balance is especially relevant when investment disputes concern environmentally sensitive sectors, such as the offshore energy industry.

For instance, the incorporation of environmental considerations in the preambles to IIAs can offer interpretative guidance when investment tribunals seek to identify the object and purpose of these agreements. ${ }^{156}$ Many new-generation IIAs have

\footnotetext{
150 Burke-White (2015), p. 2.

151 Tietje and Crow (2017), p. 88; Rees-Evans (2021), pp. 357-378.

152 See the website of UNCITRAL on the discussions of the Working Group III on Investor-State Dispute Settlement Reform: https://uncitral.un.org/en/working_groups/3/investor-state, as well as proposals for ICSID amendments: https://icsid.worldbank.org/resources/rules-amendments. These developments are not further discussed here as they fall beyond the scope of this paper.

153 Firger and Gerrard (2014), p. 261.

154 Henckels (2016), p. 49.

155 On the empirically tested limited potential of more precise language in IIAs to reduce investment disputes, see Laudal Berge (2020), pp. 925-927.

156 Take the example of the preamble to the 2012 Model US BIT, which dictates that treaty objectives must be achieved in a manner consistent with the protection of health, safety, and the environment.
} 
included explicit references to environmental protection, sustainable development or explicit mentioning of environmental agreements in their preambles. ${ }^{157}$ In that way, environmental protection is on the same plane as investment protection, which can no longer be considered the exclusive objective under IIAs. ${ }^{158}$ To provide legal certainty, States have also attempted to clarify with greater precision the normative content of the investment protection standards under new-generation IIAs. ${ }^{159}$ Specifically, States have refined the most commonly invoked standards of treatment by using interpretative language, which can guide the balancing act between investment protection and other competing objectives, such as (marine) environmental protection. ${ }^{160}$ For example, the EU-Canada Comprehensive Economic and Trade Agreement (CETA) and the new free trade agreement between the US, Mexico and Canada (USMCSA) contain chapters on environmental protection with various references to environmental agreements. ${ }^{161}$

Several new-generation IIAs have opted for a more precise prescription of the required conduct of States under the FET standard and have attempted to delimitate the concept of legitimate expectations. ${ }^{162}$ For example, CETA and the EU's proposal for the modernization of the ECT contain an exhaustive list of States' obligations under the FET standard, which appears to incorporate the recent developments in investment awards. The requirement under these agreements that the treatment afforded by the host State must be 'manifestly arbitrary' to violate the FET standard indicates the intention of the parties to set a high threshold for its breach. ${ }^{163}$ They also aim to clarify that legitimate expectations can only be protected when a specific representation by the State has been made to an investor. ${ }^{164}$ Yet, they do not specify whether a State can depart from legitimate expectations when it is deemed necessary, for example, to honour its international environmental or climate commitments.

Regarding indirect expropriation, new-generation IIAs delimit the cases of indirect expropriation, carve out the police powers doctrine and lay down specific factors

\footnotetext{
157 See the preamble to the 2018 Netherlands Model BIT. See also the preamble to the ECT, which already contained references to the United Nations Framework Convention on Climate Change and the Convention on Long-Range Transboundary Air Pollution.

158 On the relevance of preambular provisions for the interpretation of IIAs, see Clayton v. Canada, supra n. 130, para. 596.

159 Kläger (2016), p. 67; Stifter and Reinisch (2016), p. 90; Martini (2017), pp. 575-576.

160 See, inter alia, Arts. 10 and 13 of the recent EU draft proposal for the modernisation of the ECT. In addition, the EU proposal aims to fortify the right of host States to regulate, especially for mitigating climate change, 27 May 2020.

161 Art. 23(5) of CETA; Chapter 24 of the USMCA. Interestingly, the USMCA refers to UNCLOS (although the US is not a party to it) and explicitly mentions the duty to take measures against marine pollution.

162 For instance, see Art. 9(1) of the 2018 Dutch Model BIT; Art. 8.10 of CETA; Art. 3(4) of the Transatlantic Trade and Investment Partnership (TTIP); Art. 4(1) of the 2020 Brazil-India BIT; Art. 2.5.2. of the EU-Vietnam Investment Protection Agreement.

163 Henckels (2016), p. 36.

164 Art. 8.10 of CETA; Art. 9(4) of the Dutch Model BIT.
} 
to be considered by investment tribunals in order to restrict the cases in which host States are liable to pay compensation. ${ }^{165}$ Their aim is to create a rebuttable presumption that non-discriminatory regulatory measures do not constitute an expropriation, without entirely excluding such measures from the scope of compensable expropriation. ${ }^{166}$ Nonetheless, as is the case with the renewed FET provisions, the indirect expropriation clauses contain vague and malleable terms. ${ }^{167}$ Delimiting the interpretative basis of the tribunals will not necessarily limit their discretion in the application of the indirect expropriation standard, which is notoriously fact-specific. ${ }^{168}$ Regarding the requirement for proportionality analysis, ${ }^{169}$ it needs to be remembered that its impact depends on the standard of review adopted by tribunals. Using adjectives like 'manifestly' can be of little added value when the investment tribunal has the last word in clarifying the margin of acceptable regulatory autonomy of the host State.

Like exception clauses in trade law, new exception clauses purport to allow States to derogate from investment protection obligations where compliance would obstruct the host State from taking measures which are necessary for the protection of the environment. ${ }^{170}$ Thus, subject to the requirements under the exception clauses, these measures are not deemed to be violating investment protection standards. That being said, one should not overestimate the significance of exception clauses, considering that, in several cases, arbitral tribunals have accepted that measures aimed at the protection of public policy objectives do not amount to violations of investment standards. Yet it appears noteworthy that corporate social responsibility (CSR) obligations are becoming more prevalent in an attempt to promote more environmental and socially sustainable investments. ${ }^{171}$

\section{2 'Innovative' Provisions in New-Generation IIAs: Integrating Environmental Obligations or Paying Lip Service?}

Relevantly, it has been suggested that IIAs are undergoing such drastic changes that they hardly bear any resemblance to the first-generation ones. ${ }^{172}$ However, the reformed provisions in new generation IIAs should not be mistaken for a panacea for the tension between investment protection and the right and duty of States to regulate for public purposes. Preambles usually refer to environmental protection in open-ended terms and rarely refer to the environmental obligations of the host States. Substantive standards of investment protection still contain evaluative terms

\footnotetext{
165 Inter alia, see Annex 3-1, para. 3(b) of the 2019 Armenia-Singapore Agreement on Trade in Services and Investment, Annex 4, para. 3 of the 2019 EU-Vietnam Investment Protection Agreement (IPA), Annex X.11(2) of CETA, Annex I (3) of TTIP.

166 See Annex X.11(3) of CETA.

167 Henckels (2016), p. 43.

168 Martini (2017), pp. 575-576; Laudal Berge (2020), pp. 926-928.

169 See Annex 9-B(3) of CETA.

170 See, for instance, Art. 23.1(d) of the 2020 Brazil-India BIT; Art. 4.6(c) of the EU-Vietnam IPA.

171 Levashova (2020b), p. 120.

172 Nowrot (2014), p. 643.
} 
and their scarce references to proportionality provide broad discretion for investment tribunals to determine the appropriate standard of review on a case-by-case basis. Environmental chapters or protocols related to environmental aspects attached to IIAs ${ }^{173}$ are usually subordinated to their investment protection provisions ${ }^{174}$ and, so far, have played a rather marginal role in integrating the environmental obligations of host States. ${ }^{175}$

A significant problem relating to the balancing of competing obligations arises from the fact that States and relevant international organisations approach the reform of IIAs by focusing on safeguarding the right to regulate. For instance, the European Parliament, in the context of the negotiations for the conclusion of TTIP, stated that 'standards of protection and definitions of investor and investment should be drawn up in a precise legal manner protecting the right to regulate in the public interest, clarifying the meaning of indirect expropriation and preventing unfounded and frivolous claims'. ${ }^{176}$ Similarly, the EU proposal for the modernisation of the ECT has put considerable emphasis on the right to regulate. ${ }^{177}$ In particular, the EU proposal reiterates that parties to the ECT must 'effectively implement' the environmental agreements that they have ratified, and reaffirms that its parties have the right to adopt or maintain measures to further the objectives of these agreements. ${ }^{178}$ However, the problem is still framed as tension between the foreign investors' rights and the host States' right to regulate. That is not entirely correct. The author posits that besides the sovereign right to regulate, the interpreter of IIAs must also duly consider the obligation of the host State to regulate according to its environmental obligations. ${ }^{179}$ States are obliged to regulate for the protection of the marine environment: it is not just their right. Therefore, tribunals need to address interactions between investment and marine environmental law as horizontal normative interactions between two simultaneously applicable international commitments, instead of treating them as a potential conflict between investment law duties and a sovereign right of States. ${ }^{180}$ In that respect, the interest of investment protection must

\footnotetext{
173 See for instance, Energy Charter Protocol on Energy Efficiency and Related Environmental Aspects (PEEREA) to the ECT.

174 See PEEREA Art. 13(1) stating that: 'In the event of inconsistency between the provisions of this Protocol and provisions of the Energy Charter Treaty, the provisions of the Energy Charter Treaty shall, to the extent of inconsistency, prevail'.

175 In the Metaclad v. Mexico case, Mexico explicitly referred to the North American Agreement on Environmental Cooperation (NAAEC), an agreement negotiated after the conclusion of the North American Free Trade Agreement (NAFTA) and which entered into force immediately after NAFTA's entry into force. Despite the fact that all three NAFTA parties are also signatories of this agreement, the tribunal did not mention it at all and refrained from considering it to interpret the FET standard under Art. 1105 NAFTA.

176 European Parliament, 'Negotiations for the Transatlantic Trade and Investment Partnership (TTIP)', Resolution, 8 July 2015.

177 See EU Proposal on the modernization of the ECT (2020), new articles entitled 'Regulatory Measures' and 'Sustainable Development—Right to Regulate and Levels of Protection'.

178 See EU Proposal on the modernization of the ECT (2020), new article entitled 'Sustainable Development-Multilateral Environmental Agreements and Labour Conventions'.

179 Humblet and Duggal (2021), pp. 289-294.

180 Tribunals have been reluctant to deal with such horizontal normative interactions, see Azurix v. Argentina, supra n. 121, para. 261.
} 
be balanced with, for instance, the duty of the host State to protect the community interest in marine environmental protection, which transcends the benefit of a single State, or that of the totality of States. It is, instead, a duty to protect the collective interest of present and future generations.

Another critical issue is that these new IIAs do not apply retroactively. In the meantime, investment tribunals will continue to interpret and implement pre-existing IIAs. Their co-existence can accentuate the existing fragmentation of international investment law, as the newly drafted treaties are added to the current network of IIAs. ${ }^{181}$ However, it is arguable that, at least in the hypothetical case where a new-generation IIA between the host and the investor's home State exists, it could serve as proof of subsequent practice of the States for the interpretation of the earlier IIA. ${ }^{182}$ States can also address the issue by adopting, ex post, interpretative statements to clarify the scope of investment protection standards. ${ }^{183}$ Indeed, States, as the masters of their treaties, retain the right to provide an authoritative interpretation of their provisions. ${ }^{184}$ Given the fact that such interpretative guidelines will reflect the common understanding of their parties, they constitute an authentic interpretation and, therefore, the provisions of the IIAs are to be read taking them into account as 'subsequent agreement between the parties regarding the interpretation of the treaty or the application of its provisions' ${ }^{185}$ Recent IIAs explicitly recognise the authority of States to issue such authoritative interpretations of investment protection standards. ${ }^{186}$ In other investment agreements, States have delegated the power to issue an authentic interpretation of the investment treaty provisions to treaty bodies, as in the case of NAFTA. ${ }^{187}$ However, one cannot predict with certainty the normative weight that arbitral tribunals will attach to such interpretative guidelines. ${ }^{188}$

The most direct solution would be to include specific provisions governing the relationship between IIAs and non-investment duties of host States to guide the interpreter in the case of normative conflicts. ${ }^{189}$ Instead, the new-generation IIAs address normative interactions indirectly. Nonetheless, neither of the two solutions is the "master key' ${ }^{190}$ for addressing all issues arising from the potential interactions between international investment and marine environmental law. More specific IIA provisions can enhance the already existing legal tools but cannot abstractly address all the potential normative conflicts. ${ }^{191}$

\footnotetext{
181 Sornarajah (2017), p. 562.

182 Art. 31(3)(b) of the VCLT.

183 Nowrot (2014), p. 640.

184 Gazzini (2016), p. 328.

185 Art. 31(3)(a) of the VCLT.

186 For instance, see Art. 40(3) of the 2009 ASEAN Comprehensive Investment Agreement.

187 NAFTA, Art. 2001(2), which establishes a treaty body for the interpretation of the FET standard. See also CETA, Art. 8.31(3) creating a mechanism to adopt a binding interpretation of its provisions.

188 Kläger (2016), p. 77.

189 Art. 32 of the 2007 Investment Agreement for the COMESA Common Investment Area.

190 Report of the Study Group of the ILC on 'Fragmentation of International Law: Difficulties Arising from the Diversification and Expansion of International Law', para. 488.

191 For a critical assessment of the ISDS reform, see Puig and Shaffer (2018), pp. 361-408.
} 


\section{Conclusions}

In light of the stance of investment tribunals towards non-investment commitments of host States, scholars have expressed concerns with regard to the impact of investment protection standards on the capacity of States to honour their (marine) environmental obligations. As the above analysis has illustrated, the allegations concerning the far-reaching effects of investment disciplines on the regulatory discretion of States are overemphasized. Nonetheless, arbitral tribunals still have a strong influence on the interpretation and implementation of investment disciplines because they are often called to apply malleable concepts such as 'FET' or 'stricto sensu proportionality' to reach their subjective conclusions on the appropriate balance between investment protection and the protection of other common public interests. Given the discretion of investment tribunals in the interpretation of open-ended terms under IIAs, State practice has suggested the necessity to consolidate the interpretative approaches adopted by arbitral tribunals to improve legal certainty for both host States and investors. ${ }^{192}$ Although the effects of interpretation-even in the form of authentic joint interpretative declarations - are inherently limited to enabling the clarification of the interpreted rules, States - as the masters of their own treatiescontrol the fate of IIAs and the ISDS, because they have the authority to adjust, renegotiate or even dismantle the investment regime. ${ }^{193}$ In that respect, many IIAs have been undergoing a recalibration, which aims to increase the flexibility of host States in adopting the necessary regulatory measures in compliance with their international (marine environmental) commitments. However, the article recommends a cautious optimism as to the anticipated results of such reforms, which should not be mistaken for a panacea.

In the offshore energy sector, striking a fair balance between competing interests is indispensable to achieve a sustainable outcome that reconciles marine environmental protection with the protection of foreign investments. As the development of the offshore energy sector heavily depends on foreign investments, the protection of such investments continues to play an arguably significant role in attracting foreign capital and expertise. ${ }^{194}$ Therefore, undermining the investment protection system would not only affect foreign investors but could also threaten the capacity of States to safeguard energy security, ensure that their citizens enjoy the right of access to affordable and clean energy as well as comply with their commitments to transition towards a climate-neutral energy market. In that respect, investment protection should be considered as a public interest consideration and not only as a standard of protection afforded for the benefit of private actors. ${ }^{195}$ At the same time, marine environmental protection and biodiversity conservation are equally important for the continuance of the operation not only of energy investments at sea but also for any other economic activity on planet Earth. That is because of the undeniably central

\footnotetext{
192 Selivanova (2018), p. 455.

193 See, for instance, 2020 Agreement for the Termination of all Intra-EU Bilateral Investment Treaties.

194 Bonnitcha (2017).

195 Schill and Djanic (2018), p. 33.
} 
role of the oceans as natural carbon sinks, which should be appreciated for largely complementing any human-induced efforts to address the vexed challenge of climate change. ${ }^{196}$ The author posits that one should not underestimate the (perhaps untapped and imperfect) potential of the current system of IIAs and the ISDS to resolve frictions between investment and marine environmental protection. Yet, the jury is still out on the potential of new-generation IIAs and the attempted reform of ISDS in enhancing the regulatory discretion of States in adopting internationally induced marine environmental measures, as well as on their capacity to boost the fragile legitimacy of international investment law as a more balanced and, thus, sustainable international regime.

Open Access This article is licensed under a Creative Commons Attribution 4.0 International License, which permits use, sharing, adaptation, distribution and reproduction in any medium or format, as long as you give appropriate credit to the original author(s) and the source, provide a link to the Creative Commons licence, and indicate if changes were made. The images or other third party material in this article are included in the article's Creative Commons licence, unless indicated otherwise in a credit line to the material. If material is not included in the article's Creative Commons licence and your intended use is not permitted by statutory regulation or exceeds the permitted use, you will need to obtain permission directly from the copyright holder. To view a copy of this licence, visit http://creativecommons.org/licen ses/by/4.0/.

\section{References}

Acconci P (2014) The integration of non-investment concerns as an opportunity for the modernization of international investment law. In: Sacerdoti G et al (eds) General interests of host states in international investment law. Cambridge University Press, Cambridge, pp 165-193

Baetens F (2010) Foreign investment law and climate change: legal conflicts arising from implementing the Kyoto Protocol through private investment. Sustainable Development Law on Climate Change Legal Working Paper Series. https://www.files.ethz.ch/isn/138599/1_BaetensFreya\%20_ForeignInv estmentLawandClimateChange.pdf. Accessed 30 July 2021

Baker M, Dowling C (2019) Resolving climate-related disputes. The role of international arbitration. In: Bylander E et al (eds) Forward! Вперёд! Framåt! Essays in Honor of Prof Dr Kaj Hobér. Iustus Forlag, Dimograf, pp 29-42

Baltag C, Dautaj Y (2019) Investors, states, and arbitrators in the crosshairs of international investment law and environmental protection. Int Invest Law Arbit 3(1):1-77

Barral V (2016) National sovereignty over natural resources: environmental challenges and sustainable development. In: Morgera E, Kulovesi K (eds) Research handbook on international law and natural resources. Edward Elgar Publishing, Cheltenham, pp 3-25

Beharry C, Juritzky M (2015) Going green: managing the environment through international investment arbitration. Am Univ Int Law Rev 30(3):383-429

Behn D (2016) Spain wins first PV Solar Arbitration: a word of caution in using this case to predict outcome in the more than three dozen cases to come. https://www.jus.uio.no/pluricourts/english/blog/ daniel-friedrich-behn/2016-01-26-arbitration-spain.html. Accessed 30 July 2021

Behn D et al (2018) Poor states or poor governance? Explaining outcomes in investment treaty arbitration. Northwest J Int Law Bus 38:333-389

Bellantuono G (2017) The misguided quest for regulatory stability in the renewable energy sector. J World Energy Law Bus 10:274-292

196 UNFCCC Subsidiary Body for Scientific and Technological Advice, Informal Summary Report on 'Ocean and climate change dialogue to consider how to strengthen adaptation and mitigation', 29 April 2021, paras. 49-53; Schumm et al. (2021), p. 6. 
Benvenisti E (2013) Sovereigns as trustees of humanity: on the accountability of states to foreign stakeholders. Am J Int Law 107(2):295-333

Bertoli P, Crespi Reghizzi Z (2014) Regulatory measures, standards of treatment and the law applicable to investment disputes. In: Treves $\mathrm{T}$ et al (eds) Foreign investment, international law and common concerns. Routledge, Oxon, pp 26-49

Bonnitcha J (2017) Assessing the impacts of investment treaties: overview of the evidence. International Institute for Sustainable Development Report. https://www.iisd.org/sites/default/files/publications/ assessing-impacts-investment-treaties.pdf. Accessed 30 July 2021

Burke-White W (2015) Inter-relationships between the investment law and other international legal regimes, E15 Initiative. International Centre for Trade and Sustainable Development (ICTSD) and World Economic Forum. http://e15initiative.org/wp-content/uploads/2015/09/E15-InvestmentBurke-White-Final.pdf. Accessed 30 July 2021

Coop G, Seif I (2018) ECT and states' right to regulate. In: Scherer M (ed) International arbitration in the energy sector. Oxford University Press, Oxford, pp 221-249

Cotula L (2008) Reconciling regulatory stability and evolution of environmental standards in investment contracts: towards a rethink of stabilization clauses. J World Energy Law Bus 1(2):158-179

De Luca A (2014) Withdrawing incentives to attract FDI: can host countries put the genie back in the bottle? Columbia Center on Sustainable International Investment. https://doi.org/10.7916/D8154FZH. Accessed 30 July 2021

Di Benedetto S (2013) International investment law and the environment. Edward Elgar Publishing, Cheltenham

Dias Simoes F (2017) When green incentives go pale: investment arbitration and renewable energy policymaking. Denver J Int Law Policy 45(2):251-285

Dolzer R, Schreuer C (2008) Principles of international investment law. Oxford University Press, Oxford

Fernandez Masia E (2017) Spain before the international arbitration for the cut to renewable energies: a representation in three acts, for now. Cuadernos De Derecho Transnational 9(2):666-676

Firger D, Gerrard M (2014) Environmental protection. In: Mavroidis P (ed) Regulations of foreign investment: challenges for international harmonization. World Scientific Publishing, Singapore, pp 231-275

Foster C (2017) Respecting regulatory measures: arbitral method and reasoning in Philip Morris v Uruguay Tobacco Plain Packaging Case. Rev Eur Compar Int Environ Law 26(3):287-297

Gallagher N (2018) ECT and renewable energy disputes. In: Scherer M (ed) International arbitration in the energy sector. Oxford University Press, Oxford, pp 250-275

Gardiner R (2017) Treaty interpretation, 2nd edn. Oxford University Press, Oxford

Gazzini T (2016) Interpretation of international investment treaties. Hart Publishing, Oxford

Giannopoulos N (2019) Global environmental regulation of offshore energy production: searching for legal standards in ocean governance. Rev Eur Compar Int Environ Law 28(3):289-303

Gordon K, Pohl J (2011) Environmental concerns in international investment law: a survey. OECD Working Papers on International Investment, 2011/01. https://www.oecd.org/daf/inv/investment-policy/ WP-2011_1.pdf. Accessed 30 July 2021

Hanni M et al (2011) Foreign direct investment in renewable energy: trends, drivers and determinants. Transnation Corporat 20(2):29-66

Henckels C (2012) Indirect expropriation and the right to regulate: revisiting proportionality analysis and the standard of review in investor-state arbitration. J Int Econ Law 15(1):223-255

Henckels C (2016) Protecting regulatory autonomy through greater precision in investment treaties: the TPP, CETA and TTIP. J Int Econ Law 19(1):27-50

Hirsch M (2006) Interactions between investment and non-investment obligations in international investment law. Hebrew University International Law Research Paper No 14-06. https://ssrn.com/abstr act $=947430$. Accessed 30 July 2021

Hirsch M (2008) Conflicting obligations in international investment law: investment tribunals' perspective. In: Shany Y, Broude T (eds) The shifting allocation of authority in international law: considering sovereignty, supremacy and subsidiarity. Hart Publishing, Portland, pp 321-343

Hirsch M (2011) Between fair and equitable treatment and stabilization clause: stable legal environment and regulatory change in international investment law. J World Invest Trade 12:783-806

Humblet F, Duggal K (2021) If you are not part of the solution, you are part of the problem: Article 37 of the EU Charter as a defence for climate change and environmental measures in investor-state arbitrations. Eur Invest Arbitrat Law Rev 5(1):266-295 
Joffe G et al (2009) Expropriation of oil and gas investments: historical, legal and economic perspectives in a new age of resource nationalism. J World Energy Law Bus 2(1):3-23

Kim R, van Asselt H (2016) Global governance: problem shifting in the anthropocene and the limits of international law. In: Morgera E, Kulovesi K (eds) Research handbook on international law and natural resources. Edward Elgar Publishing, Cheltenham, pp 473-495

Kingsbury B, Schill S (2010) Public law concepts to balance investor's rights with state regulatory actions in the public interest- the concept of proportionality. In: Schill S (ed) International investment law and comparative public law. Oxford University Press, Oxford, pp 75-104

Kläger R (2011) Fair and equitable treatment and sustainable development. In: Cordonier-Segger M et al (eds) Sustainable development in world investment law. Wolters Kluwer, New York, pp 241-259

Kläger R (2016) Revisiting treatment standards-fair and equitable treatment in light of sustainable development. In: Hindelang S, Krajewski M (eds) Shifting paradigms in international investment law-more balanced, less isolated, increasingly diversified. Oxford University Press, Oxford, pp $65-80$

Laudal Berge T (2020) Dispute by design? Legalization, backlash, and the drafting of investment agreements. Int Stud Quart 64(4):919-928

Laudal Berge T, Berger A (2019) Does investor-state dispute settlement lead to regulatory chill? Global evidence from environmental regulation. https://www.peio.me/wp-content/uploads/2019/ 01/PEIO12_Paper_78.pdf. Accessed 30 July 2021

Levashova Y (2020a) Fair and equitable treatment and investor's due diligence under international investment law. Neth Int Law Rev 67:233-255

Levashova Y (2020b) The right of access to water in the context of investment disputes in Argentina: Urbaser and beyond. Utrecht Law Rev 16(2):110-124

Lindroos A (2005) Addressing norm conflicts in a fragmented legal system: the doctrine of lex specialis. Nordic J Int Law 74:27-66

Ludeke J (2018) Exploitation of offshore wind energy. In: Solomon M, Markus T (eds) Handbook on marine environmental protection: science, impacts and sustainable management. Springer, Cham, pp 165-188

Mann H (2002) The right of states to regulate and international investment law. International Institute for Sustainable Development Report. https://www.iisd.org/pdf/2003/investment_right_to_regul ate.pdf. Accessed 30 July 2021

Mann H (2015) ISDS: who wins more, investors or states? https://arbitrationlaw.com/library/isdswho-wins-more-investors-or-states-journal-damages-international-arbitration-vol-2-no-2. Accessed 30 July 2021

Martin T (2011) Dispute resolution in the international energy sector: an overview. J World Energy Law Bus 4(4):332-368

Martini C (2017) Balancing investor's rights with environmental protection in international investment arbitration: an assessment of recent trends in investment treaty drafting. Int Law 50(3):529-584

Mbengue M, Raju D (2014) Energy, environment and foreign investment. In: De Brabandere E, Gazzini $\mathrm{T}$ (eds) Foreign investment in the energy sector: balancing private and public interests. Brill/Nijhoff, Leiden/Boston, pp 171-191

McLachlan C (2005) The principle of systemic integration and Article 31(3)(c) of the Vienna Convention. Int Compar Law Quart 54(2):279-320

Michaels R, Pauwelyn J (2012) Conflict of norms or conflict of laws? Different techniques in the fragmentation of public international law. Duke J Comp Int Law 22(3):349-376

Miles K (2008) International investment law and climate change: issues in the transition to a low carbon world. SIEL Working Paper 27/28. https://doi.org/10.2139/ssrn.1154588. Accessed 30 July 2021

Mills A (2014) The balancing (and unbalancing?) of interests in international investment law and arbitration. In: Douglas Z, Pauwelyn J, Viñuales E (eds) The foundations of international investment law: bringing theory into practice. Oxford University Press, Oxford, pp 437-498

Nowrot K (2014) How to include environmental protection, human rights and sustainability in international investment law? J World Invest Trade 15:612-644

Orakhelashvili A (2006) Peremptory norms in international law. Oxford University Press, Oxford

Ortino F (2017) Investment treaties, sustainable development and reasonableness review: a case against strict proportionality balancing. Leiden J Int Law 30(1):71-91

Ortino F (2018) The obligation of regulatory stability in the fair and equitable treatment standard: how far have we come? J Int Econ Law 21(4):845-865 
Paine J (2017) Failure to take reasonable environmental measures as a breach of investment treaty? J World Invest Trade 18:745-754

Paine J (2018) On investment law and questions of change. J World Invest Trade 19:173-207

Pauwelyn J (2003) Conflict of norms in public international law: how WTP law relates to other rules in international law. Cambridge University Press, Cambridge

Pauwelyn J (2004) Bridging fragmentation and unity: international law as a universe of inter-connected islands. Michigan J Int Law 25:903-916

Pavel C (2009) Normative conflicts in international law. San Diego Law Rev 46:883-906

Prislan V (2013) Non-investment obligations in investment treaty arbitration: towards a greater role for states? In: Baetens F (ed) Investment law within international law: integrationist perspectives. Cambridge University Press, Cambridge, pp 450-481

Puig S, Shaffer G (2018) Imperfect alternatives: institutional choice and the reform of investment law. Am Soc Int Law 112(3):361-409

Rees-Evans L (2021) The protection of the environment in international investment agreements-recent developments and prospects for reform. Eur Investment Law Arbitrat Rev 5(1):357-391

Romanin Jacur F (2015) The Vatenfall v Germany disputes: finding a balance between energy investments and public concerns. In: Levashova Y et al (eds) Bridging the gap between international investment law and the environment. Eleven Publishing, the Hague, pp 339-357

Sadat-Akhavi S-A (2003) Methods of resolving conflicts between treaties. Martinus Nijhoff, Leiden/ Boston

Schill S, Djanic V (2018) Wherefore art thou? Towards a public interest-based justification of international investment law. ICSID Rev 33(1):29-55

Schreuer C (2007) Fair and equitable treatment in investment treaty law: introduction. In: Ortino F et al (eds) Investment treaty law: current issues II. British Institute of International and Comparative Law, London, pp 92-120

Schumm et al (2021) Giving greater attention to the ocean in the development and implementation of the Post-2020 Global Biodiversity Framework. IDDRI, Study N. 04/21

Scovazzi T (2012) Maritime accidents with particular emphasis on liability and compensation for damage from the exploitation of mineral resources of the seabed. In: De Guttry A et al (eds) International disaster response law. T.M.C Asser Press, The Hague, pp 287-320

Seck A (1996) Investing in the former Soviet Union's oil industry: the Energy Charter Treaty and its implications for mitigating political risk. In: Wälde T (ed) The Energy Charter Treaty: an East-West gateway for investment \& trade. Kluwer Law International, London, pp 110-134

Selivanova Y (2018) Changes in renewables support policy and investment protection under the Energy Charter Treaty: analysis of jurisprudence and outlook for the current arbitration cases. ICSID Rev 33(2):433-455

Sicilianos L-A (2002) The classification of obligations and the multilateral dimension of the relations of international responsibility. Eur J Int Law 13(5):1127-1145

Simma B (2011) Foreign investment arbitration: a place for human rights? Intl Compar Law Q 60(3):573-596

Sornarajah M (2017) The international law on foreign investment, 4th edn. Cambridge University Press, Cambridge

Spears S (2010) The quest for policy space in a new generation of international investment agreements. J Int Econ Law 13(4):1037-1075

Stifter L, Reinisch A (2016) Expropriation in the light of the UNCTAD investment policy framework for sustainable development. In: Hindelang S, Krajewski M (eds) Shifting paradigms in international investment law: more balanced, less isolated, increasingly diversified. Oxford University Press, Oxford, pp 81-96

Tienhaara K (2011) Regulatory chill and the threat of arbitration: a view from political science. In: Brown C, Miles K (eds) Evolution in investment treaty law and arbitration. Cambridge University Press, Cambridge, pp 606-628

Tietje C, Crow K (2017) The reform of investment protection rules in CETA, TTIP, and other recent EU FTAs: convincing? In: Griller S et al (eds) Mega-regional trade agreements: CETA, TTIP, and TiSA - new orientations for EU external economic relations. Oxford University Press, Oxford, pp $78-100$

Trevisanut S (2013) Foreign investments in the offshore energy industry: investment protection $v$. energy security $v$. the protection of the marine environment. In: Treves $\mathrm{T}$ et al (eds) Foreign investment, international law and common concerns. Routledge, Oxon, pp 247-264 
Trevisanut S (2020) Decommissioning of offshore installations: a fragmented and ineffective international regulatory framework. In: Banet C (ed) The law of the seabed-access, uses and protection of seabed resources. Brill, Leiden/Boston, pp 431-453

Trevisanut $\mathrm{S}$ et al (2020) Regime interaction in ocean governance: problems, theories and methods. Brill, Leiden/Boston

Trevisanut S, Giannopoulos N (2018) Investment protection in offshore energy production: bright sides of regime interaction. J World Invest Trade 19:789-827

Vandevelde K (2011) Model bilateral investment treaties: the way forward. Southwest J Int Law 14(4):307-314

Viñuales J (2012) Foreign investment and the environment in international law. Cambridge University Press, Cambridge

Viñuales J (2017) Investor diligence in investment arbitration: sources and arguments. ICSID Rev $32(2): 346-370$

Viñuales J (2019) Foreign investment and the environment in international law: current trends. In: Miles $\mathrm{K}$ (ed) Research handbook on environment and investment law. Edward Elgar, Cheltenham, pp $12-37$

Vranes E (2009) The definition of norm conflict in international law and legal theory. Eur J Int Law 17(2):395-418

Wälde T, Kolo A (2001) Environmental regulation, investment protection and 'regulatory taking' in international law. Int Compar Law Q 50(4):811-848

Whitsitt E, Bankes N (2013) The evolution of international investment law and its application to the energy sector. Alberta Law Rev 51(2):207-247

Yang P-K (2018) The margin of appreciation debate over novel cigarette packaging regulations in Philip Morris v Uruguay-A step toward a balanced standard of review in investment disputes. Brill Open Law 1:91-111

Zannoni D (2020) The legitimate expectation of regulatory stability under the Energy Charter Treaty. Leiden J Int Law 33(2):451-466

Publisher's Note Springer Nature remains neutral with regard to jurisdictional claims in published maps and institutional affiliations.

\section{Authors and Affiliations}

\section{Nikolaos Giannopoulos ${ }^{1}$}

Nikolaos Giannopoulos

n.giannopoulos@uu.nl

1 Department of International and European Law, Faculty of Law, Economics and Governance, Utrecht University, Utrecht, The Netherlands 